International Journal of Instruction e-ISSN: 1308-1470 • www.e-iji.net

Article submission code: 20200402135059

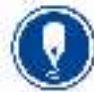

Received: 02/04/2020 Revision: 10/12/2020
July $2021 \bullet$ Vol.14, No.3

p-ISSN: 1694-609X

pp. 241-254

Accepted: 02/01/2021

OnlineFirst: 06/05/2021

\title{
The Effect of Education System Components on the Quality of Vocational High School Graduates
}

Mochamad Cholik

Universitas Negeri Surabaya, Indonesia, mochamadcholik@unesa.ac.id

Muchlas Samani

Universitas Negeri Surabaya, Indonesia,msamani@unesa.ac.id

I. G. P. Asto Buditjahjanto

Universitas Negeri Surabaya, Indonesia, asto@unesa.ac.id

Aldila Rahma Putri

Universitas Pamulang, Indonesia, aldilarahmaputri@gmail.com

Vocational High Schools are designed to prepare students to enter the workforce, so that the graduates' absorption, waiting periods and the first salaries become the indicator of effectiveness. However, the Central Statistics Agency's data shows that the open unemployment for Vocational High Schools graduates is very high and exceeds the Senior High School graduates. The condition is not just because of low economic growth, but also because the quality of vocational graduates has not been as expected in the workforce. This study aims to find the causality relationship based on the components of the education system on the National Education Standards. The population of this research is all Vocational High Schools in Indonesia totaling 13,710 units, while the sample is Vocational High Schools that were accredited in 2018. The data is taken from the results of accreditation at the School Accreditation Board and then analyzed by using SEM (structural equation modeling), so that the effect of each component on the other components can be known in producing the Vocational High Schools graduates. From the results of this analysis, the critical components can be found, so that if the performance of these components is increased in a chain, it can improve the quality of vocational graduates effectively and efficiently.

Keywords: education system components, graduate quality, vocational high school, vocational education, workforce

\section{INTRODUCTION}

Vocational High School is designed to prepare students to enter the workforce, although it does not close the opportunity for graduates to go on to college. When the economic

Citation: Cholik, M., Samani, M., Buditjahjanto, I. G. P. A., \& Putri, A. R. (2021). The Effect of Education System Components on the Quality of Vocational High School Graduates. International Journal of Instruction, 14(3), 241-254. https://doi.org/10.29333/iji.2021.14314a 
level of most communities is not good, young people need jobs immediately, the existence of vocational schools is very important because it can be one of the ladders of social mobility for children of underprivileged families. Therefore, one of the Vocational High Schools' effectiveness is the absorption of graduates, the waiting period, and the salary/income they receive (Newhouse \& Suryadarma, 2009). The waiting period is considered important, because people will not be able to be unemployed forever, so that when the waiting period is too long they will accept jobs below what they should, resulting in job bumping.

However, the data of the Central Statistics Bureau shows the number of unemployed Vocational High School graduates is $11.24 \%$ and even exceeds the Senior High School graduates. With a total of 13,710 Vocational High School and 4,904,031 students (Kemdikbud, 2017) the unemployed is $11.24 \%$, which is a large enough number so that it requires serious thought to overcome them. If it is not immediately resolved, the large unemployment may become a social problem that spreads everywhere. Therefore, it can be understood when the Governor of East Java, Kofifah Indarparawangsa will redesign the pattern of education in Vocational High Schools by cooperating with The Business and Industrial World to produce graduates that are in line with the needs of the workforce. The idea of the Governor of East Java requires serious study and effort because it involves many agencies, which the experience shows it is not easy to be done in Indonesia (Lee Kuan Yew School of Public Policy, 2016).

The occurrence of considerable unemployment is certainly influenced by Indonesia's economic growth in the last few years that is only around 5\%. However, if we look at the data that the number of unemployed Vocational High School graduates is higher than that of Senior High School graduates, it seems that in addition to being due to low economic growth, the quality of Vocational High School graduates also influences the occurrence of unemployment. Newhouse and Suryadarma's study (2009) concludes that the quality of Vocational High School graduates is indeed not good, so The Business and Industrial World is often unsatisfied.

In addition to competencies that are not following the desired standards, The Business and Industrial World also complained about the work attitudes of Vocational High School graduates who were not following the work requirements and thus required quite long training. Advertisements in newspapers that always include work experience as one of the requirements for applying for a job as if it states that Vocational High School graduates are not ready to work, so it requires training first (Samani, Warsono, and Rahayu, 2014). Therefore increasing the quality of Vocational High School graduates is a necessity. This fact prompted the President to issue Presidential Instruction number 9 in 2016 concerning Vocational High School Revitalization. This Presidential Instruction ordered various related institutions to support the improvement of the education quality in Vocational High Schools.

In Government Regulation Number 32 in 2013, it is stated that eight standards must be the education standard, namely the competence of graduates, content, processes, educators and education staff, assessment, management, costs, and infrastructure. In the concept of systems thinking (Senge, 2000), these standards can be understood as sub- 
systems or components in the education system, whereas in ex post facto research designs (Simon and Goes, 2013), they can be interlaced as interrelated variables. This study wants to find out how the causality relationship between these variables in producing SMK graduates and finding which latent variables are the most dominant influence on other variables so that the Pareto concept can be applied to improve the quality of Vocational High School graduates.

By using the concept of the educational process and the eight components in education standards are interpreted as variables, the graduate competency variable is the end of the educational processes series, while the other seven variables are latent variables that directly or indirectly affect the competency of graduates. However, in a system with many sub-components, there are always variables that have a strong influence but also variables that have little effect (Senge, 1997). Variables like this are usually only needed to support other variables in carrying out their functions

The main controller of the learning process is the teacher by utilizing teaching material (curriculum) and the available learning tools so that some experts argue that the teacher is one of the keys in the learning process. Whatever education policy is made and whatever facilities and infrastructure are available, finally the teacher uses it in the learning process. The teacher becomes "the man behind the gun" in the learning process. The research of John Hattie (2008), Moursheed and Barber (2010) shows the teacher's contribution to student learning outcomes is above 50\%, which is why Finland and Japan, known as countries with good quality education, pay close attention to the teacher in building education (Shalberg, 2011; Yamasaki, 2016).

In empirical experience, schools often change significantly when changing principals. Management and leadership applied by new principal affect teacher performance, affect the budget allocation and utilization of facilities, so that ultimately affects the learning process implemented by teachers (Leithwood et al., 2004; Emir, 2013; Hartati et al., 2020; Gunawan et al., 2020; Pipattanasuk \& Songsriwittaya, 2020). The management and leadership of school principals also affect the school climate, because interactions between school members change (Duan and Du, 2018).

The learning concept, curriculum (including assessment patterns), infrastructure, and funding are the used variables by teachers in the learning process. Its existence to a certain extent is necessary but how functional its role is in the learning process, is highly dependent on the teacher. Therefore, these four variables are often referred to as supporting variables.

Based on the description above, it can be concluded that the seven variables derived from the National Education Standards are variables that affect the quality of graduates. Some variables directly influence the quality of Vocational High School graduates, but some variables influence through other variables and there are even variables that depend on the operationalization of other variables. The learning process variable is a variable that is thought to have a direct effect on the quality of graduates. The quality of learning is influenced by teacher performance, while teacher performance is influenced by the school management. The main objective of this research is to find a causal 
relationship between factors (teacher, learning, curriculum, infrastructure, budget, school management) that have a strong influence on the quality of Vocational High School graduates, so that they can be used as a basis for effective quality improvement.

\section{Literature Review}

Schools (including Vocational High School) must be understood as a system (Senge, 2000), so to improve its performance, the system must be assessed first. By understanding the causality relationships between sub-systems in it, it will be found where the dominant sub-systems' influence on other sub-systems is, so that the efforts to improve performance can be focused on the sub-systems. By using the Pareto concept, an effective and efficient treatment model can be developed to improve the system performance. The results of the Education Endowment Fund study (2016) and Friedman's (2013) observations of schools in Shanghai can be used as a comparison to find the dominant sub-system.

Graduate competence is the result of student learning, so the quality of learning is very influential on it (Osorio, Fasih, Patrinos, and Santibanez, 2009; Moradi, Hussin, and Barzegar, 2012). In this context, the learning process can occur in the classroom, workshop, studio, and field and even outside the class hours, namely the internalization of students towards the ongoing school culture (Duan and Du, 2018). What interactions are experienced by students in the learning process in the classroom and internalization of school culture is what ultimately shapes student behavior. Even in the process of character building, school culture often plays a more important role.

Students identify themselves with what happens every day in school (Waston, 2008). Skills are highly needed by graduates of Vocational High Schools (Rahdiyanta, Nurhadiyanto, \& Munadi, 2019; Hartati, Suryadarma \& Hanum, 2020; Smith, 2002; McGrath \& Powell, 2016; Klatt et al., 2017; Vaughan, 2017; Hurrell, 2017 2016; Cimatti, 2016). Vocational High School graduates need to have superior quality in a career in the working world (Dietrich \& Kracke, 2009; Guan et al., 2017; Kuijpers \& Scheerens, 2006; Leung et al., 2011; Suryadi et al., 2020).

Looking at the relationship between variables (teacher, learning, curriculum, infrastructure, budget, school management), the following framework can be developed. Graduates competency is produced by the learning process that is followed by students while in school, while the learning process is controlled by the teacher by utilizing the curriculum, assessment patterns, and the available educational infrastructure. Teacher performance is influenced by the school management, because the principal's management pattern can affect teacher performance, manage the budget and infrastructure in schools. The causal relationship between these variables is shown in Figure 1. 


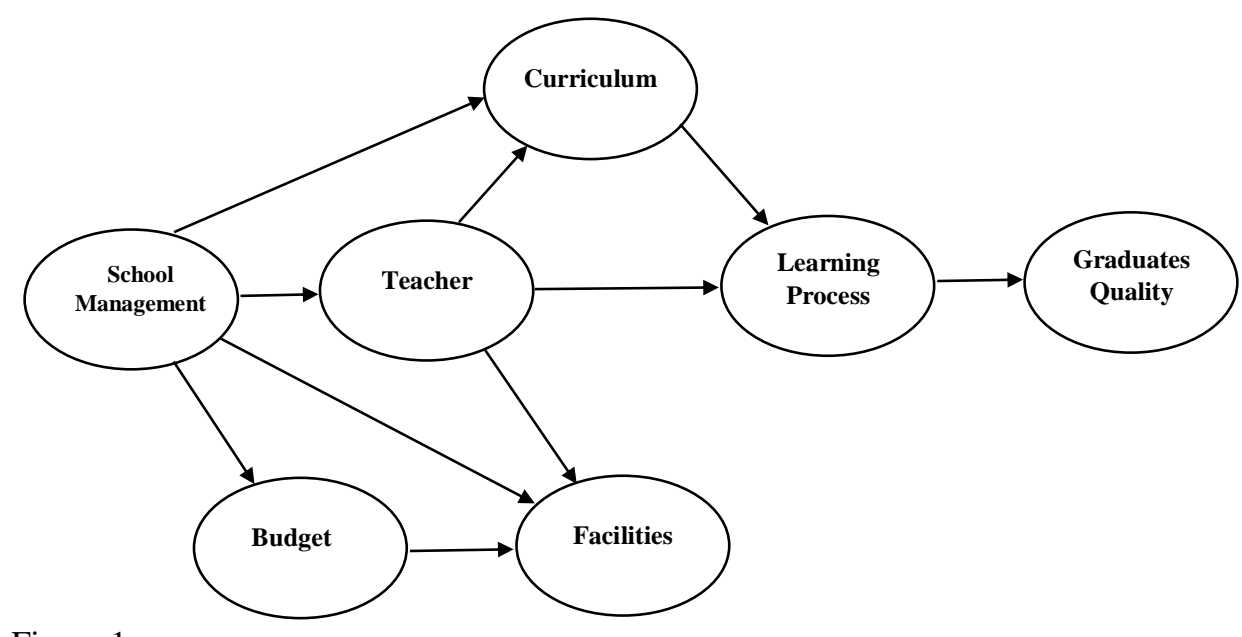

Figure 1

The causality relationship between determining variables the quality of Vocational High School graduates.

\section{Hypothesis}

Based on the paradigm of causality in Figure 1, the following research hypotheses are formulated:

- Learning influences the competency of Vocational High School graduates.

- Teachers influence on the learning of Vocational High School.

- Curriculum influences the learning process in Vocational High School.

- Infrastructure influences the for learning in Vocational High School

- The teachers influence on the curriculum in Vocational High School.

- The teachers influence on the infrastructure in Vocational High School.

- The budget influences the facilities in Vocational High School.

- School management influences the teachers in Vocational High School schools.

- School management influences the curriculum in Vocational High School.

- School management influences the Vocational High School budget.

- School management influences the infrastructure in Vocational High School.

\section{METHOD}

\section{Research Method}

This year's research aims to find the causality relationship between various components (sub-systems) in the education system of Vocational High School to produce quality graduates. The systems and sub-systems as research variables and causality relationships have already taken place, so they cannot be treated. Therefore, ex post facto research methods (causal-comparative) are suitable to be used (Cohen. Manion \& Morrison, 2011). 
It is realized that the variables in the education system in Vocational High Schools are very numerous and some are even undetected, so the variables from the sub-system of the National Education Standards are considered as standard because they are developed based on studies at the Ministry of Education and Culture.

\section{Population and Sample}

The population of this study is Vocational High Schools in Indonesia, both public and private with 13,710 units. The sampling method is done by purposive sampling, namely the Vocational High Schools that were accredited in 2018. All Vocational High Schools that are accredited in 2018 will be sampled, so that the number is large enough (estimated at 1200) so that they can give an idea of the actual condition in Vocational High Schools.

\section{Instruments, Data Collection Methods and Data Analysis}

The research data are secondary data from the results of school accreditation. However, the accreditation instrument will be examined and selected which the indicators and items that are consistent with the research objectives, so that the obtained data is relevant. After selecting the relevant indicators and items, then data tabulation is performed

Data collection is done by taking secondary data at the School Accreditation Agency Data Center, by combing the variables, indicators, and relevant items in advance. Based on the results, the data will be tabulated, so it is a score for each indicator variable. The data analysis use SEM (Structural Equation Modeling), so that the index of influence of each variable toward the others can be seen. The results of the SEM will be used to interpret which variables have a direct or indirect influence on the quality of Vocational High School graduates.

\section{FINDINGS AND DISCUSSION}

The SEM test results look like Table 1. If we look at the coefficient of the relationship between each variable (in this context as a component of the education system) and is associated with the hypothesis proposed in the literature review section can be explained as follows. 
Table 1

Structural equation model (SEM) test result

\begin{tabular}{llll}
\hline Path Coefficients & & & \\
\hline & Estimate & SE & CR \\
\hline School Management $\geq$ Curriculum & 0,446 & 0,016 & 27.34 \\
\hline School Management $\geq$ Teacher & 0,730 & 0,015 & 48,62 \\
\hline School Management $\geq$ Budge & 0,686 & 0,019 & 35,66 \\
\hline School Management $\geq$ Facilities & 0,322 & 0,019 & 16,98 \\
\hline Curriculum $\geq$ Learning Process & 0,372 & 0,013 & 29,32 \\
\hline Teacher $\geq$ Curriculum & 0,338 & 0,016 & 21,6 \\
\hline Teacher $\geq$ Learning Process & 0,267 & 0,015 & 17,81 \\
\hline Teacher $\geq$ Facilities & 0,416 & 0,020 & 20,65 \\
\hline Budget $\geq$ Facilities & 0,150 & 0,020 & 7,63 \\
\hline Learning Process $\geq$ Graduates Quality & 0,757 & 0,014 & 54,21 \\
\hline Facilities $\geq$ Learning Process & 0,096 & 0,012 & 7,97 \\
\hline
\end{tabular}

- Hypothesis 1, which tells that the learning process has an effect on the competence of Vocational High School graduates proven to have a coefficient of 0.757 . This means that $75.7 \%$ of the Vocational High School graduate's quality can be explained through what happens in the learning process experienced by students. It should be noted that what is meant as a learning process in this study includes the used evaluation.

- Hypothesis 2, which tells that the teacher's influence on learning in Junior High School is proven by a coefficient of 0.267 . It means that $26.7 \%$ of the learning process can be explained by the teacher's performance while teaching

- Hypothesis 3, which tells that the curriculum influences the learning process in Vocational High School, it is proved by a coefficient of 0.372 . This means that $37.2 \%$ of the Vocational High School learning process can be explained by the applied curriculum by the teacher in the learning process.

- Hypothesis 4, which tells that the infrastructure of the learning process in Vocational High Schools is proven by a coefficient of 0.096 , meaning that $9.6 \%$ of the learning process in Vocational High Schools can be explained by the existence of facilities and infrastructure in schools

- Hypothesis 5, which says that the teacher influences the curriculum in Vocational High Schools, it is proven with a coefficient of 0.338 , meaning that $33.8 \%$ of the used curriculum in Vocational High Schools can be explained by the teacher's performance in teaching

- Hypothesis 6, which says the teacher influences the facility in Vocational High Schools, it is proven by the coefficient of 0.416 , meaning that the utilization of facilities in schools can be explained by the teacher's performance.

- Hypothesis 7, which says that the budget affects the facility in the Vocational High School, it is proven with a coefficient of 0.150 . This means that the existence of facilities in Vocational High School can be explained by the available budget 
- Hypothesis 8, which says that the school management affects the teachers in Vocational High School with a coefficient of 0.730, means that $73 \%$ of teacher performance can be explained through applied school management.

- Hypothesis 9, which says that school management affects the curriculum in Vocational High Schools, it is proven by a coefficient of 0.446. This means that $44.7 \%$ of the implemented curriculum by teachers can be explained through the running school management

- Hypothesis 10, which says that school management affects the Vocational High School budget, it is proven by a coefficient of 0.686 . This means that $68.6 \%$ of the vocational budget can be explained through the ongoing school management.

- Hypothesis 11, which says that school management toward facilities in Vocational High Schools, is proven by a coefficient of 0.322 , meaning that $32.2 \%$ of the facility's existence in Vocational High Schools can be explained through the applied school management.

The final goal of this study is not merely to test hypotheses but to find out which components or sub-systems have the most dominant influence on the quality of Vocational High School graduates, both direct and indirect influences. If the component can be found, according to Pareto's theory, the quality improvement of the Vocational High School graduates can be done more efficiently by giving treatment to that subsystem. Therefore, although all SEM analysis results in Table 1 show that the research hypothesis is proven with Alpha 0.05, the analysis will be continued by looking for the variable that has the most dominant influence on the quality of Vocational High School graduates.

For this purpose, the generated coefficients from the SEM analysis are integrated into the module of the relationship of causality between the sub-systems (system components) of education in Vocational High School that the results are shown in Figure 2. 


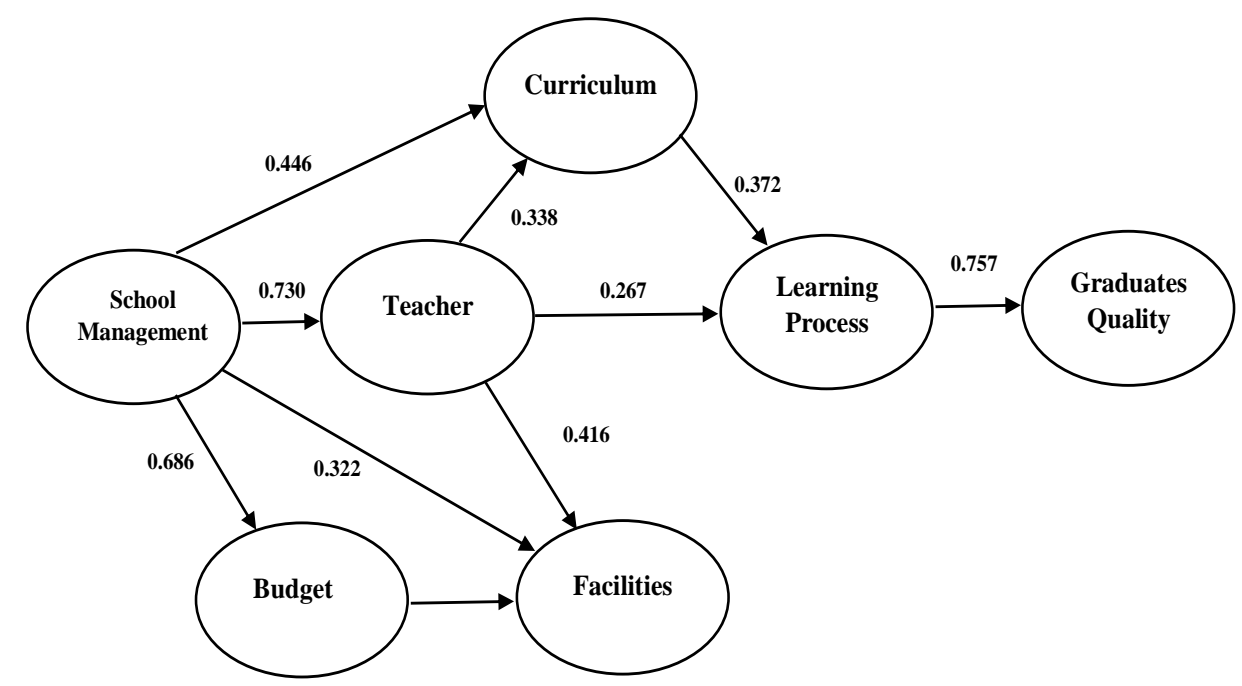

Figure 2

SEM test result

The data in Figure 2 shows that the learning process is one component that influences the quality of graduates with a very high coefficient, which is 0.757 . It is suspected that the influence of other components, such as the teacher, curriculum, and infrastructure actually exists but is not directly because of the learning process. The flow of thinking like that can be understood because the curriculum and facilities can affect the quality if they are used by the teacher in the learning process.

The triangular relationship between the teacher, curriculum, and learning process can be explained as follows. Teacher performance outside teaching material directly influences the learning process. For example the daily behavior of the teacher, discipline, and so on. Besides that, the teacher also has an indirect influence on the learning process through the selection of teaching materials and how to guide students in understanding the teaching materials.

Figure 2 also shows the effect of the infrastructure and components in the learning process is the smallest $(0.096)$. Indeed, the SEM test is still statistically significant, the coefficient is very small. It is suspected that the ability and motivation of teachers to utilize learning facilities are less than optimal. The points of the winning instruments are not much in the presence of facilities but also their maintenance and usage.

The effect of the budget on infrastructure is also relatively small (0.150), although statistically significant, it is precisely school management and teachers that influence infrastructure, respectively 0.322 and 0.416 , it is expected because of the relation to the principal's policy in the procurement of school infrastructure and teacher policies in using school facilities in the learning process. The expectation was reinforced by the very strong influence of school management on the school budget $(0.686)$. 
In the end, the school management is the source. School management affects the performance of teachers with a coefficient of 0.730 and affects the used curriculum with a coefficient of 0.466 , affects the school budget with a coefficient of 0.686 , and influences school infrastructure with a coefficient of 0.322 . This data phenomenon can be understood because indeed school management can reach all components in the education system in schools.

\section{School management and teachers as key components}

As mentioned earlier, the end of this study is to look for components or sub-systems where critical factors occur to improve the quality of education. If Figure 2 is examined and linked to organizational practice in schools and Pareto theory, then school management and teachers are key components to improve the quality of education in Vocational High Schools, even if they have to take one component of the education system, in schools, school management becomes the highest priority.

Leithwoodm Louis, Anderson and Walstroom (2004) categorize schools as loose organizations, meaning that school governance does not use a strict model as in the military, so that the principal has a wide range of space in building school management. Field facts show the school structure changes significantly when the school principal changes. This is different from an organization where the system is standard, the standard operating procedures are strict, so that the leadership does not have wide space to improvise.

How can the school management flow improve the quality of graduates, even though the principal does not directly meet with students in learning? Thinking system theory developed by Peter Senge (1997) can explain. School management can make efforts to unite the vision (shared vision) with teachers and all school residents, so that synergy occurs to achieve shared goals and targets. School management can also improve the capacity of teachers and education personnels, according to the tasks they carry (personnel mastery) and assure them that they are certainly able to carry out their duties and the school can achieve what it aspires (mental model)

As explained by Abu-Dhuhuo (2007) that student learning outcomes are a function of the learning innovations carried out by the teacher, whereas to encourage teachers to innovate, they need some basic requirements, namely abilities, opportunities, and awareness of the goals to be achieved. Meeting these basic requirements can be done by the school management. Abu-Duhuo mentioned that as the main task of school leadership in improving student learning outcomes, teacher performance always innovates in managing the learning process.

How school management techniques carry out that idea, Sallis (2002) thought can explain. According to Sallis, in school management that applies customer satisfaction, the teachers and other staff in the school are the first customers. School management that can facilitate them to be satisfied will make them can work optimally. As the first customer, the job of the teacher and other staff in the school is to help and facilitate the second customer, the student, so that they can learn well. In turn, school management, 
both directly and indirectly, must reach third customers, namely parents of students and the community to be satisfied with the services provided by the school.

This principle is also applied in the school-based management in Indonesia with the concept of an inverted pyramid. In this concept, commanding management is changed to serve or facilitate management. If on the old management concept, the teacher's task is to manage learning in such a way that students learn well, then in service management, the main task of the teacher is to facilitate learning well. If the old management concept, the principal's job is to facilitate teachers and other personnel so that they can work well to serve students. In turn, the supervisor and the education office must facilitate the principal to serve the teacher well.

If this is the central role of school management, why is the teacher component also a critical factor in improving the quality of education? In short, because what is sought by the school management is ultimately the teacher who carries out the learning. While performance is a combination of function and competence and commitment. Although school management strives to improve their work competency and commitment, certain personal factors influence teachers.

Certainly increasing teacher competency and commitment cannot negate the potential of its basic characteristics. As mentioned by Hettie (2008) what can be strived to be improved in humans is $51 \%$ while the other $49 \%$ is the basic potential and has been carried since they were born. Therefore, getting a good teacher is also an important key in efforts to improve the quality of Vocational High Schools.

\section{CONCLUSION}

Based on the analysis, the following conclusions can be drawn (a) The learning process has a significant effect on the competence of Vocational High School graduates; (b) Teacher competence and commitment affect learning in Vocational High School; (c) Curriculum influences the learning process in SMK; (d) Infrastructure influences firing in Vocational High School; (e) Teacher competence and commitment affect the application of curriculum in Vocational High School; (f) Teacher competence and commitment affect the use of infrastructure in Vocational High School; (g) The budget influences the utilization of facilities in Vocational High School; (h) School management influences the competency and commitment of Vocational High School teachers; (i) School management influences curriculum implementation in Vocational High School; (j) School management influences the use of budget in Vocational High School; (k) School management influences the use of facilities in Vocational High School. In addition to the things written above that the teacher, the learning process, and the quality of graduates are the most dominant workflow series. The teacher's commitment to work will in turn determine the quality of learning that results in graduates' quality. School management turns out to be the main key in improving the quality of Vocational High School graduates, it is recommended that in conditions of limited resources, having a good headmaster and fostering him/her will be able to manage schools innovatively is the most effective way. The teacher remains the dominant factor, so to get a good teacher and develop them will be a very important 
thing related to teaching and learning activities which in turn determines the quality of Vocational High School graduates.

\section{ACKNOWLEDGEMENT}

Researchers would like to thank the research grant funds from Universitas Negeri Surabaya.

\section{REFERENCES}

Cimatti, B. (2016). Definition, development, assessment of soft skills, and their role for the quality of organizations and enterprises. International Journal for Quality Research, 10(1), 97-130.

Cohen, Louis, Lawrence Manion \& Keith Morrison. (2011). Research Methods in Education: $7^{\text {th }}$ Edition. London: Routledge.

Dietrich, J., \& Kracke, B. (2009). Career-specific parental behaviors in adolescents' development. Journal of Vocational Behavior, 75(2), 109-119.

Duan, Xiaoju, and Xiangyun. (2018). "School Culture and School Effectiveness: The Mediating of Teachers' Job Satisfaction" in International Journal of Learning. Teaching and Educational Research, 17(5), 15-25.

Education Endowment Fund. (2016). What Works at What Cost: Teaching and Learning Toolkit

Emir, O. (2013). The effect of training on vocational high school students in their professional development. Procedia-Social and Behavioral Science, 106, 2274-2738.

Friedman L. Thomas. (2013). The Shanghai Secret. Artikel dimuat di Harian New York Time tanggal 22 Oktober 2013.

Guan, Y., Jiang, P., Wang, Z., Mo, Z., \& Zhu, F. (2017). Self-referent and other-referent career successes, career satisfaction, and turnover intention among Chinese employees: the role of achievement motivation. Journal of Career Development, 44(5), 379-393.

Gunawan, Kosim, \& Lestari, P. A. S. (2020). Instructional Materials for Discovery Learning with Cognitive Conflict Approach to Improve Vocational Students' Achievement. International Journal of Instruction, 13(3), 433-444.

Hartati, M. S., Suryadarma, IGP, \& Hanum, F. (2020). Implementation of the Parenting Model to Improve Understanding of Reproduction Health of Vocational High School Students. International Journal of Instruction, 13(1), 215-224.

Hartati, M. S., Suryadarma, IGP, \& Hanum, F. (2020). Implementation of the Parenting Model to Improve Understanding of Reproduction Health of Vocational High School Students. International Journal of Instruction, 13(1), 215-224.

Hattie, John. 2008. "Validating the Specification of Standards for Teaching: Application to the National Board for Professional Teaching Standard' Assessment" in Lawrence Ingwarson \& John Hettie (eds). Assessing Teachers for Professional Certification: The 
First Decade of National Board for Professional Teaching Standards. Howard House, Wagen Lane, UK: Emerald Group Publishing Ltd.

Hu, S., Hood, M., \& Creed, P. A. (2018). Career goal importance as a moderator in the relationship between career feedback and career-related stress. Journal of Career Development, 45(1), 3-18.

Hurrell, S. A. (2016). Rethinking the soft skills deficit blame game: employers, skills withdrawal, and the reporting of soft skills gaps. Human Relations, 69(3), 605-628.

Karen Vaughan. (2017)."The role of apprenticeship in the cultivation of soft skills and dispositions." Journal of Vocational Education \& Training, 69(3), 540-557.

Kementerian Pendidikan dan Kebudayaan-Pusat Data dan Statistik Pendidikan. (2017). Statistik SMK. Jakarta: Kemdikbud RI.

Klatt, M, Clarke, K., \& Nicky, D. (2017). Working their way to school completion: a snapshot of School-based Apprenticeships and Traineeships for young Australians. Journal of Vocational Education \& Training, 69(2), 473-494.

Kuijpers, M. A. C. T., \& Scheerens, J. (2006). Career competencies for the modern career. Journal of Career Development, 32(4), 303-319.

Lee Kuan Yew School of Public Policy. (2016). Vocational Education and Technical Training in Indonesia: Challenges and Opportunities for the Future. Singapore: National Technological University.

Leithwood, Kenneth, Karen Seashore Louis, Stephen Anderson, and Kyla Wahlstrom. (2004). Review of research How leadership influences student learning. Minneapolis: Center for Applied Research and Educational Improvement-University of Minnesota.

Leung, S. A., Hou, Z.-J., Gati, I., \& Li, X. (2011). Effects of parental expectations and cultural-values orientation on career decision-making difficulties of Chinese University students. Journal of Vocational Behavior, 78(1), 11-20.

McGrath, S., \& Powell, L. (2016). Skills for sustainable development: Transforming vocational education and training beyond 2015. International Journal of Educational Development, 50(2), 12-19.

Moradi, Saeid, Sufean Bin Hussin, and Nader Barzegar. (2012). School-Based Management (SBM), Opportunity or Threat (Education systems of Iran). International Conference on Education and Educational Psychology (ICEEPSY 2012).

Newhouse, David, and Daniel Suryadarma. (2009). The Value of Vocational Education High School Type and Labor Market Outcomes: The World Bank Human Development Network Social Protection and Labor Division in Indonesia. Washington DC: The World Bank.

Osario, Felipe Barrera, Tazen Faish, Harry Anthony Patrinos, Lucrecia Santibanez. (2009). Decentralized Decision-Making in Schools The Theory and Evidence on School-Based Management. Washington DC: The World Bank. 
Pipattanasuk, T., \& Songsriwittaya, A. (2020). Development of an Instructional Model with Augmented Reality Technology for Vocational Certificate Students. International Journal of Instruction, 13(3), 539-554.

Rahdiyanta, D., Nurhadiyanto, D., \& Munadi, S. (2019). The Effects of Situational Factors in the Implementation of Work-Based Learning Model on Vocational Education in Indonesia. International Journal of Instruction, 12(3), 307-324.

Sahlberg, Pasi. (2011). Finnish Lessons: Mengajar Lebih Sedikit, Belajar Lebih Banyak ala Finland. Diterjemahkan dari Finnish Lessons: What Can the World Learn from Educational Change in Finland? New York: Teachers College Press.

Sallis, Edward. (2002). Total Quality Management in Education: Third Edition. London: Kogan Page Ltd.

Samani, Muchlas, Warsono dan Yuni Sri Rahayu. (2014). Rethinking Education in the $21^{\text {st }}$ Century: An Indonesia Case. Makalah disampaikan pada ASAIHL International Conference di NTU Singapore tanggal 3-4 Desember 2014.

Senge, P. et. al. (2000). School That Learn: A Fifth Discipline Resource. London: Nicholas Brealey Publishing.

Simon, Marylin K., and Jim Goes. (2013). ExPost Facto Research: Dissertation and Scholarly Research.

Smith, E. (2002). Theory and practice: the contribution of off-the-job training to the development of apprenticeship and trainee. Journal of Vocational and Education Training, 54(3), 431-456.

Suryadi, B., Sawitri, D. R., Hayat, B., \& Putra, M. D. K. (2020). The Influence of Adolescent-Parent Career Congruence and Counselor Roles in Vocational Guidance on the Career Orientation of Students. International Journal of Instruction, 13(2), 45-60.

The Education Endowment Fund. (2016). Teaching Learning Toolkit in The Economist.com. June 16, 2016.

Yamasaki, Hirotoshi. (2016). Teachers and Teacher Education in Japan. Bull. Grad. School Educ. Hiroshima Univ., Part III, No. 65, 2016, 19-28. 